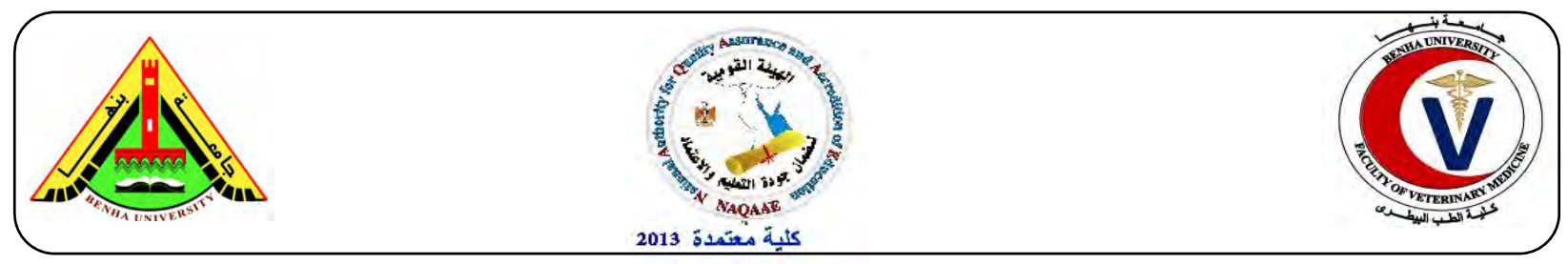

\title{
Biochemical alterations of resveratrol on oxidative stress in experimental induced non - alcoholic fatty liver disease in rats
}

Omayma A.R. AboZaid, Omnia M. AbdEl-hamid, Shimaa A. E. Atwa

Department of Biochemistry, Faculty of Veterinary Medicine, Benha University.

\section{A B S T R A C T}

The main objective of this study is to investigate the alterations of resveratrol on oxidative stress in experimental induced nonalcoholic fatty liver disease (NAFLD) in rats. Thirty male albino rats were divided into three groups (10 rats each). The first group fed a normal diet and represents the control group. The second group (NAFLD) fed normal diet enriched with $1 \%$ cholesterol and $2 \%$ coconut oil and act as positive control. The third group fed on normal diet enriched with $1 \%$ cholesterol and $2 \%$ coconut oil and Resveratrol at a rat dose $3 \mathrm{mg} / \mathrm{kg}$ body weight / daily /6weeks intra peritoneal (i.p) . Samples collected after 2, 4 and 6 weeks after treatment. serum was used for estimation of serum nitric oxid ( NO), L- Malondialdehyde (L-MDA) and Immunoglobulins as serum Immunoglobulin A (IgA) Immunoglobulin $\mathrm{G}$ ( $\mathrm{IgG}$ ) and liver function tests as serum Aspartate aminotransferase (AST), serum Alanine amino transferase (ALT), serum Gamma glutamyl transferase (GGT). Hepatic tissues for Enzymatic Antioxidants as Liver Catalase ( Liver CAT),Liver superoxide dismutase(Liver SOD), Non Enzymatic Antioxidants as Liver Reduced Glutathione (Liver GSH). Results revealed a significantly decrease in serum NO, Liver CAT, Liver SOD, Liver GSH More ever serum L-MDA, serum AST,ALT, GGT were significantly increase concentration In addition to Serum IgA, IgG were also significantly increase . The behavioral biochemical results indicated treatment with Resveratrol showed a significant changes and improves these parameters.

Keywords: NAFLD, Resveratrol, Antioxidants, Immunoglobulins, Liver function tests

(http://www.bvmj.bu.edu.eg)

(BVMJ-28(1): 166-177, 2015)

\section{INTRODUCTION}

Nonalcoholic fatty liver disease (NAFLD) is now recognized as the most common cause of cryptogenic cirrhosis. However, the diagnosis of cirrhosis in patients with NAFLD appears to be delayed compared with those with other chronic liver diseases and thus carries a higher mortality rate (Jeanne, et al., 2003). Oxidative stress occurs when oxygen free radicals are generated in excess through a reduction of oxygen or when antioxidant defense systems are impaired. When neural cells are under oxidative stress, excessive reactive oxygen species (ROS) are produced that may induce neuronal death (Slatter, et al., 2000). Antioxidants represent a first line body defense against oxidative stress produced by the generation of free radicals and reactive oxygen species (ROS).
Unchecked, these compounds can cause considerable damage to tissues. Antioxidants are compounds that prevent oxidation by donating reducing equivalents to inactivate reactive compounds. Antioxidants can be classified as either non enzymatic antioxidants such as Glutathione which react directly with raicals or toxins, or enzymatic, CAT, SOD, GSH, which donate reducing equivalents through the action of a specific enzyme (Walter, et al., 2006).

Polyphenolic compounds that can be roughly classified in to flavonoid and non flavonoid compounds, non flavonoids include hydroxycinnamic acid, benzoic acid, tannins and stilbenes which including RSV (Reuters, 2010). Resveratrol (3,5,4'- 
trihydroxy-trans-stilbene) is a stilbenoid, a type of natural phenol, and a phytoalexin produced naturally by several plants when under attack by pathogens such as bacteria or fungi (Steven Reinberg, 2014). Resveratrol, a dietary polyphenol has been shown to possess potent anti-oxidant as well as anti-inflammatory properties, mediates induction of anti-oxidant enzymes, modulates lipid metabolism, cardioprotection while attenuating hepatic lipid peroxidation (Bass et al., 2007). The aim of this study to alter ate of resveratrol on oxidative stress in experimental induced NAFLD in rats.

\section{MATERIALS AND METHODS}

\subsection{Animals and chemicals:}

A total of thirty Male white albino rats, 68 weeks age and weighting $(150-180 \mathrm{~g})$ were used in the experiment. Rats were housed in a separate metal cage with free access to water. Rats were kept under constant and nutritional environmental condition throughout the experimental period. Rats were left for 15 days before beginning of experiment for acclimatization.

Cholesterol and coconut oil were purchased from El-Goumhouria Co. for Trading Chemicals, Egypt.

NAFLD was induced by continuous supplementation of high fat diet (prepared by High Cholesterol (1\% wt/wt) and (Coconut oil $2 \% \mathrm{wt} / \mathrm{wt}$ ) to normal ration) according to NRC, 1995.

\subsection{Resveratrol:}

Physical properties: Resveratrol 3, 5, 4'trihydroxystilbene is a stilbenoid derivatives and highly soluble in 5\% ethanol. Resveratrol (purity $\sim 99 \%$ ) was purchased from Schnell dorf, Germany through the Egyptian International Center for Import Cairo, Egypt. Resveratrol was freshly prepared in 5\% Ethanol, and administered to rats at a dose of $3 \mathrm{mg} / \mathrm{kg}$ b. wt/ daily I / P, (Jian-Gang Zou, et al., 2003).

\subsection{Experimental design:}

Rats were divided into 3 main groups (10 per each) main groups classified as follow: Group I was fed on normal diet and served as control group.

Group II was fed on high fat diet (Normal NAFLD) for 12 weeks.

Group III was fed on high fat diet (NAFLD) and treated resveratrol with $3 \mathrm{mg} / \mathrm{kg}$.

\subsection{Sampling:}

After overnight fasting blood samples was collected from all animal groups (control and experimental groups) after12 weeks for detection of NAFLD (hyperlipidemia) .then samples were collected after 2, 4and 6 weeks from onset of treatment.

\subsubsection{Blood samples:}

Blood Samples were collected from Medial Canthes of eye and collected indry, clean and screw capped tubes then rats decapitated for liver tissue removal. Sera were separated by centrifugation at 2500 r.p.m for 15 minutes. The clean clear serum was separated by Pasteur pipette and kept in a deep freeze at $-20 \mathrm{C}$ till used for determination of the biochemical Parameters: Serum NO( Vodovotz, 1996), Serum L-MDA (Mesbah, et al., 2004), Immunogloblines a Serum IgA ( whicher, et al., 1984), $\operatorname{IgG}$ ( whicher, et al., 1984), liver function tests as serum AST (Murray, 1984), ALT (Murray,1984), GGT (Beleta and Gella, 1990)andTissues as Liver Enzymatic Antioxidants as (Liver CAT (Luck, 1974),Liver SOD( Nishikimi, etal.,1972),Non Enzymatic Antioxidants as Liver GSH (Moron, et al., 1979).

\subsubsection{Tissue Sample:}

Liver specimens were preserved in $10 \%$ buffered neutral formalin and subjected for Histopathological Examination according to the technique described by (Bancroft and Stevens, 1996)

\subsection{Statistical analysis:}

The obtained data were analyzed using the statistical package for social science 
(SPSS, 13.0 software, 2009), for obtaining mean and standard deviation and error. The data were analyzed using one-way ANOVA to determine the statistical significance differences among groups. Duncan's test was used for making a multiple comparisons among the groups for testing the inter-grouping.

\section{RESULTS}

The results in table (1,2and 3$)$ revealed that rats fed on hyperlipidemic diet in NAFLD showed A significant decrease on serum NO concentration compared with normal control group at 2, 4and 6 weeks In Experimental induced NAFLD in rats.

Resveratrol treatment exhibited a significant decrease in serum NO concentration in rats after 2 , 4and 6 weeks compared with control NAFLD group.

The results in table $(1,2$ and 3$)$ revealed that rats fed on hyperlipidemic diet in NAFLD showed A significant increase in serum LMDA concentration compared with normal control group at 2, 4and 6 weeks In Experimental induced NAFLD in rats.

Resveratrol treatment exhibited a significant decrease in serum L-MDA concentration in rats after 2 , 4and 6 weeks compared with control NAFLD group.

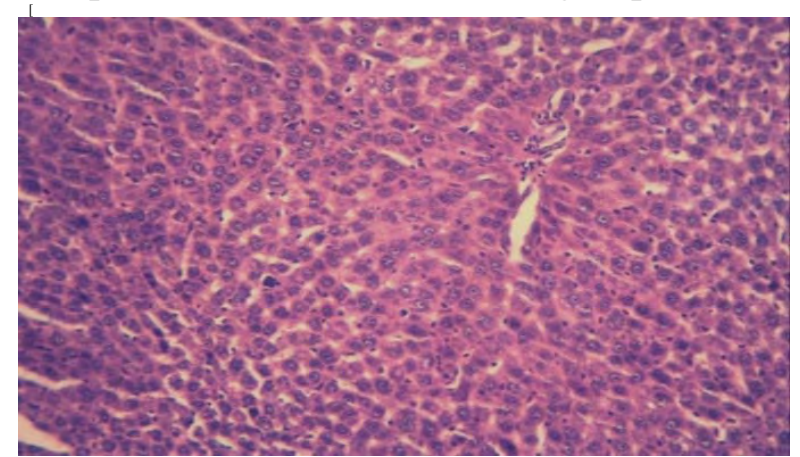

Figure (1): liver of normal control rats showing normal histological structure of the liver, normal hepatic lobules and hepatocytes, Group (1)

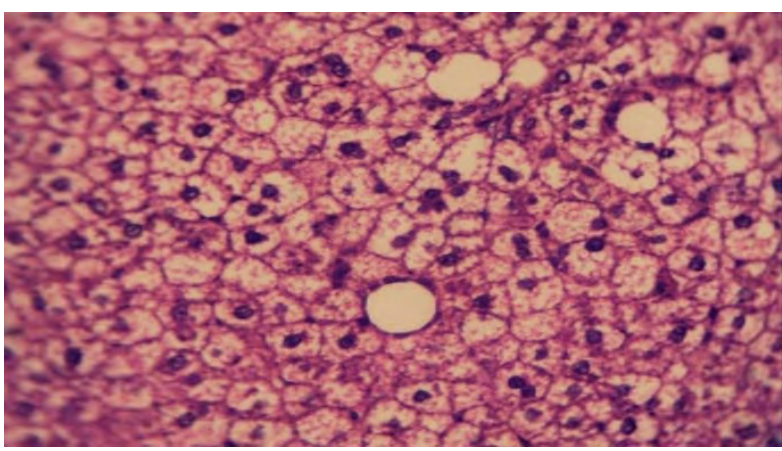

Figure (2): Liver of NAFLD rats, the microscopical examination of liver showing sever congestion of the central vein and portal blood vessels. The hepatocytes showing sever degenerative changes in the form of vacuolar degeneration in the cytoplasm of hepatocytes in which the hepatocytes showing the presence fibrillated threads in the cytoplasm, mild degree of fatty change should be seen. in some of hepatocytes in which the hepatocytes giving signet ring shape as it contained flattened squeezed nucleus to one side, Group II

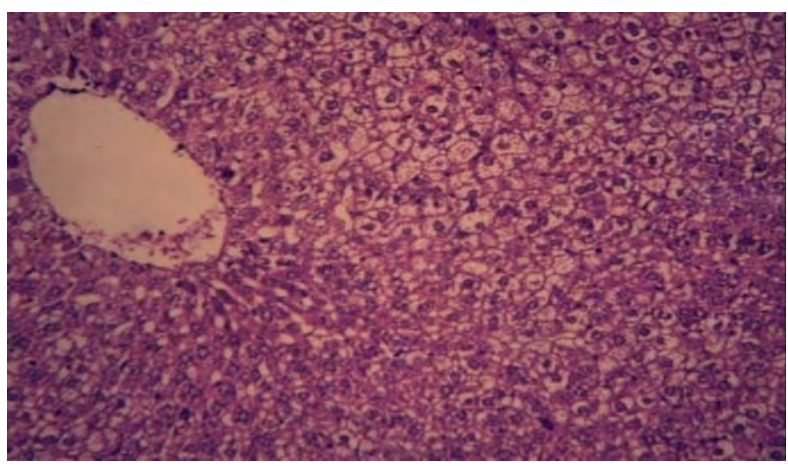

Figure (3): liver of resveratrol treated rats, showing mild congestion of blood vessel newly formed bile ductules will also detected some of hepatocytes pickned red nucleus (karylytic), Group III

Data in Table (1, 2 and 3 ) recorded that rats fed hyperlipidemic diet in NAFLD showed A significant increase in serum $\operatorname{IgA}, \operatorname{IgG}$ concentration compared with normal control group at 2, 4and 6 weeks In Experimental induced NAFLD in rats.

Resveratrol treatment exhibited a significant decrease in serum $\operatorname{IgA}, \operatorname{IgG}$ concentration in rats after 2, 4 and 6 weeks compared with control NAFLD group.

The results in table (1,2 and 3$)$ stated that rats fed hyperlipidemic diet in NAFLD showed A significant increase in serum AST, ALT, GGT concentration compared with normal control group at 2, 4and 6 weeks In Experimental induced NAFLD in rats. 
Table (1) Effect of resveratrol on serum nitric oxide (NO), L-MDA, serum IgA, IgG, serum AST, ALT, GGT, tissue as liver CAT, liver SOD, liver GSH after 2 weeks in experimentally induced non-alcoholic fatty liver disease in rats

\begin{tabular}{|c|c|c|c|c|c|c|c|c|c|c|}
\hline $\begin{array}{l}\text { Parameter/ } \\
\text { group }\end{array}$ & $\begin{array}{c}\mathrm{NO} \\
\mathrm{mmol} / 1\end{array}$ & $\begin{array}{c}\text { L- } \\
\text { MDA } \\
\text { n mol/1 }\end{array}$ & $\begin{array}{c}\mathrm{IgA} \\
\mathrm{ng} / \mathrm{ml}\end{array}$ & $\begin{array}{c}\mathrm{IgG} \\
\mathrm{ng} / \mathrm{ml}\end{array}$ & $\begin{array}{l}\mathrm{AST} \\
\mathrm{U} / \mathrm{L}\end{array}$ & ALT U/L & $\begin{array}{l}\text { GGT } \\
\text { U/L }\end{array}$ & $\begin{array}{c}\text { Liver } \\
\text { CAT } \\
\text { gm/tissue }\end{array}$ & $\begin{array}{l}\text { Liver } \\
\text { SOD } \\
\text { U/gm } \\
\text { tissue }\end{array}$ & $\begin{array}{l}\text { Liver } \\
\text { GSH } \\
\text { ng/gm } \\
\text { /tissue }\end{array}$ \\
\hline \multirow{2}{*}{ Group I } & $112.13^{\mathrm{a}}$ & $48.83^{\mathrm{e}}$ & $2.59^{\mathrm{ef}}$ & $29.68^{\mathrm{e}}$ & $220.38^{\text {bcd }}$ & $90.66 \mathrm{e}^{\mathrm{eh}}$ & $55.52^{\text {efg }}$ & $56.34^{\mathrm{eb}}$ & $45.81^{\mathrm{a}}$ & $10.03^{\mathrm{a}}$ \\
\hline & \pm 4.11 & \pm 4.60 & \pm 0.20 & \pm 0.51 & \pm 6.37 & \pm 4.86 & \pm 5.09 & \pm 3.93 & \pm 0.96 & \pm 0.37 \\
\hline \multirow{2}{*}{ Group II } & $72.86^{\mathrm{e}}$ & $173.36^{\mathrm{a}}$ & $4.79^{c}$ & $80.37^{\mathrm{a}}$ & $259.16^{\mathrm{ab}}$ & $194.83^{\mathrm{a}}$ & $65.68^{\text {de }}$ & $40.96^{\text {cde }}$ & $22.35^{\text {efg }}$ & $5.68^{\mathrm{ef}}$ \\
\hline & \pm 12.46 & \pm 3.23 & \pm 0.05 & \pm 3.22 & \pm 25.90 & \pm 14.85 & \pm 5.36 & \pm 0.98 & \pm 5.38 & \pm 0.39 \\
\hline \multirow{2}{*}{ Group III } & $71.54^{\mathrm{e}}$ & $94.23^{b}$ & $4.26^{\mathrm{d}}$ & $59.26^{\mathrm{b}}$ & $236.94^{\mathrm{abc}}$ & $133.04^{\mathrm{fg}}$ & $59.10^{\mathrm{e}}$ & $39.67^{\text {cde }}$ & $20.13^{\text {gh }}$ & $6.39^{\mathrm{cd}}$ \\
\hline & \pm 2.67 & \pm 1.48 & \pm 0.07 & 1.88 & 22.51 & 3.01 & 3.00 & \pm 1.86 & \pm 0.66 & \pm 0.21 \\
\hline
\end{tabular}

Data are presented as (Mean \pm S.E). S.E $=$ Standard error. Mean values with different superscript letters in the same column are significantly different at $(P \leq 0.05)$

Table (2) Effect of resveratrol on serum nitric oxide (NO), L-MDA, serum IgA, IgG, serum AST, ALT, GGT, tissue as liver CAT, liver SOD, liver GSH after 4 weeks in experimentally induced non-alcoholic fatty liver disease in rats

\begin{tabular}{|c|c|c|c|c|c|c|c|c|c|c|}
\hline $\begin{array}{l}\text { Parameter/ } \\
\text { group }\end{array}$ & $\begin{array}{c}\mathrm{NO} \\
\mathrm{mmol} / 1\end{array}$ & $\begin{array}{c}\text { L- } \\
\text { MDA } \\
\mathrm{n} \mathrm{mol} / 1\end{array}$ & $\begin{array}{c}\operatorname{IgA} \\
\mathrm{ng} / \mathrm{ml}\end{array}$ & $\begin{array}{c}\mathrm{IgG} \\
\mathrm{ng} / \mathrm{ml}\end{array}$ & $\begin{array}{l}\text { AST } \\
\text { U/L }\end{array}$ & ALT U/L & $\begin{array}{c}\text { GGT } \\
\text { U/L }\end{array}$ & $\begin{array}{c}\text { Liver } \\
\text { CAT } \\
\text { gm/tissue }\end{array}$ & $\begin{array}{l}\text { Liver } \\
\text { SOD } \\
\text { U/gm } \\
\text { tissue }\end{array}$ & $\begin{array}{c}\text { Liver } \\
\text { GSH } \\
\text { ng/gm } \\
\text { /tissue }\end{array}$ \\
\hline Group I & $\begin{array}{c}107.79^{\mathrm{abc}} \\
\pm 3.17\end{array}$ & $\begin{array}{c}61.77^{\mathrm{de}} \\
\pm 3.48\end{array}$ & $\begin{array}{l}3.00^{\mathrm{e}} \\
\pm 0.15\end{array}$ & $\begin{array}{l}25.00^{\mathrm{e}} \\
\pm 1.25\end{array}$ & $\begin{array}{c}173.89^{\text {def }} \\
\pm 7.81\end{array}$ & $\begin{array}{c}115.02^{\text {ehg }} \\
\pm 3.14\end{array}$ & $\begin{array}{c}57.88^{\mathrm{ef}} \\
\pm 2.91\end{array}$ & $\begin{array}{c}55.49^{\mathrm{ab}} \\
\pm 3.10\end{array}$ & $\begin{array}{c}42.31^{\mathrm{ab}} \\
\pm 1.95\end{array}$ & $\begin{array}{c}6.78^{\mathrm{b}} \\
\pm 0.26\end{array}$ \\
\hline Group II & $\begin{array}{c}87.39^{\text {cde }} \\
\pm 8.79\end{array}$ & $\begin{array}{c}127.35^{\mathrm{a}} \\
\pm 5.50\end{array}$ & $\begin{array}{c}6.23^{\mathrm{a}} \\
\pm 0.09\end{array}$ & $\begin{array}{c}92.03^{\mathrm{ab}} \\
\pm 6.41\end{array}$ & $\begin{array}{c}236.88^{\mathrm{abc}} \\
\pm 11.86\end{array}$ & $\begin{array}{l}199.37^{b} \\
c_{ \pm 13.67}\end{array}$ & $\begin{array}{c}69.31^{\mathrm{bc}} \\
\pm 1.73\end{array}$ & $\begin{array}{l}39.07^{\mathrm{f}} \\
\pm 3.03\end{array}$ & $\begin{array}{c}24.37^{\mathrm{efg}} \\
\pm 6.10\end{array}$ & $\begin{array}{l}6.88^{\mathrm{ef}} \\
\pm 0.17\end{array}$ \\
\hline Group III & $\begin{array}{l}77.77^{\mathrm{e}} \\
\pm 1.37\end{array}$ & $\begin{array}{c}77.58^{\mathrm{cd}} \\
\pm 1.48\end{array}$ & $\begin{array}{l}4.00^{\mathrm{d}} \\
\pm 0.04\end{array}$ & $\begin{array}{c}31.80^{\text {de }} \\
\pm 1.44\end{array}$ & $\begin{array}{c}196.33^{\text {cde }} \\
\pm 6.85\end{array}$ & $\begin{array}{c}138.54^{\mathrm{fg}} \\
\pm 5.73\end{array}$ & $\begin{array}{c}67.46^{\mathrm{cd}} \\
\pm 1.79\end{array}$ & $\begin{array}{c}43.08^{\mathrm{cd}} \\
\pm 1.25\end{array}$ & $\begin{array}{c}22.39^{\text {efgh }} \\
\pm 0.69\end{array}$ & $\begin{array}{c}6.78^{\mathrm{b}} \\
\pm 0.26\end{array}$ \\
\hline
\end{tabular}

Data are presented as (Mean \pm S.E). $\quad$ S.E $=$ Standard error. Mean values with different superscript letters in the same column are significantly different at $(P \leq 0.05)$.

Table (3) Effect of resveratrol on serum nitric oxide (NO), L-MDA, serum IgA, IgG, serum AST, ALT, GGT, tissue as liver CAT, liver SOD, liver GSH after 6 weeks in experimentally induced non-alcoholic fatty liver disease in rats.

\begin{tabular}{|c|c|c|c|c|c|c|c|c|c|c|}
\hline $\begin{array}{l}\text { Parameter/ } \\
\text { group }\end{array}$ & $\begin{array}{c}\mathrm{NO} \\
\mathrm{mmol} / 1\end{array}$ & $\begin{array}{c}\text { L-MDA } \\
\mathrm{n} \mathrm{mol} / 1\end{array}$ & $\begin{array}{c}\text { IgA } \\
\mathrm{ng} / \mathrm{ml}\end{array}$ & $\begin{array}{c}\mathrm{IgG} \\
\mathrm{ng} / \mathrm{ml}\end{array}$ & $\begin{array}{l}\text { AST } \\
\text { U/L }\end{array}$ & ALT U/L & $\begin{array}{l}\text { GGT } \\
\text { U/L }\end{array}$ & $\begin{array}{c}\text { Liver } \\
\text { CAT } \\
\text { gm/tissue }\end{array}$ & $\begin{array}{l}\text { Liver } \\
\text { SOD } \\
\text { U/gm } \\
\text { tissue }\end{array}$ & $\begin{array}{c}\text { Liver } \\
\text { GSH } \\
\text { ng/gm } \\
\text { /tissue }\end{array}$ \\
\hline Group I & $\begin{array}{c}107.01^{\mathrm{abc}} \\
\pm 5.13\end{array}$ & $\begin{array}{l}51.85^{\mathrm{e}} \\
\pm 6.32\end{array}$ & $\begin{array}{l}2.20^{\mathrm{de}} \\
\pm 0.12\end{array}$ & $\begin{array}{c}32.76^{\mathrm{de}} \\
\pm 2.80\end{array}$ & $\begin{array}{c}162.42^{\mathrm{ef}} \\
\pm 4.00\end{array}$ & $\begin{array}{c}105.06^{\mathrm{eh}} \pm \\
2.21\end{array}$ & $\begin{array}{l}47.80^{\mathrm{f}} \\
\pm 1.68\end{array}$ & $\begin{array}{l}64.25^{\mathrm{a}} \\
\pm 1.68\end{array}$ & $\begin{array}{c}32.96^{\text {cde }} \\
\pm 1.98\end{array}$ & $\begin{array}{l}8.24^{\mathrm{b}} \\
\pm 0.38\end{array}$ \\
\hline Group II & $\begin{array}{l}83.59^{\text {de }} \\
\pm 14.90\end{array}$ & $\begin{array}{c}139.98^{b c} \\
\pm 14.36\end{array}$ & $\begin{array}{l}5.25^{\mathrm{b}} \\
\pm 0.09\end{array}$ & $\begin{array}{l}43.22^{c} \\
\pm 2.54\end{array}$ & $\begin{array}{c}218.46^{\mathrm{bcd}} \\
\pm 20.24\end{array}$ & $\begin{array}{c}167.84^{\mathrm{cde}^{\mathrm{de}}} \\
13.82\end{array}$ & $\begin{array}{l}55.54^{\mathrm{f}} \\
\pm 2.59\end{array}$ & $\begin{array}{c}34.99^{\mathrm{ef}} \\
\pm 3.44\end{array}$ & $\begin{array}{c}30.09^{\text {de }} \\
\pm 5.14\end{array}$ & $\begin{array}{l}6.58^{\mathrm{de}} \\
\pm 0.20\end{array}$ \\
\hline Group III & $\begin{array}{c}52.84^{\mathrm{ef}} \\
\pm 3.69\end{array}$ & $\begin{array}{c}100.28^{\mathrm{b}} \\
\pm 2.95\end{array}$ & $\begin{array}{c}3.69^{\mathrm{e}} \\
\pm 0.03\end{array}$ & $\begin{array}{l}35.15^{\mathrm{d}} \\
\pm 0.70\end{array}$ & $\begin{array}{c}145.09^{\mathrm{ef}} \\
\pm 2.21\end{array}$ & $\begin{array}{c}106.26^{\mathrm{h}} \\
\pm 2.33 \\
\end{array}$ & $\begin{array}{l}29.68^{\mathrm{i}} \\
\pm 0.96\end{array}$ & $\begin{array}{c}33.41^{\text {ef }} \\
\pm 6.67\end{array}$ & $\begin{array}{c}15.67^{\mathrm{hi}} \\
\pm 0.52\end{array}$ & $\begin{array}{r}7.18^{\mathrm{d}} \\
\pm 0.28 \\
\end{array}$ \\
\hline
\end{tabular}

Data are presented as (Mean \pm S.E). $\quad$ S.E $=$ Standard error. Mean values with different superscript letters in the same column are significantly different at $(P \leq 0.05)$. 
Resveratrol treatment exhibited a significant decrease in serum AST, ALT, GGT concentration in rats after 2, 4and 6 weeks compared with control NAFLD group.

Data in Table ( 1,2 and 3) found that rats fed hyperlipidemic diet in NAFLD showed A significant decrease in Liver CAT, Liver SOD and Liver GSH concentration compared with normal control group at 2, 4 and 6 weeks In experimental induced NAFLD in rats.

Resveratrol treatment exhibited a significant decrease after 2,4 weeks ,a significant increase after 6 weeks in Liver CAT, a significant decrease after 2,4 and 6 weeks in Liver SOD and a significant increase after 2, 4 and 6 weeks in Liver GSH concentration in rats after 2,4 and6 weeks compared with control NAFLD group.

\section{DISCUSSION}

Data presented in Table (1,2and 3) revealed that a significant decrease in Serum NO concentration after 2,4 and 6weeks compared with the normal control group. These results were nearly similar to Stenvinkel, (2001) revealed that a significant decrease in Serum NO may be due to the various functions of ECs (endothelial cells) such as the control of fibrinolysis, coagulation, vascular tone, growth and immune response.In addition to Oyadomari, et al., (2001); Emanuela Esposito, et al., (2013) found that a significant decrease in Serum NO may be due to the citrulline/NO cycle is regulated by ASS (arginino succinate synthase). NO is synthesized from the conversion of 1arginine into l-citrulline mediated by eNOS, andASS catalyses the rate-limiting step in the arginineregeneration through the citrulline/NO cycle and appearsto be coordinately regulated with eNOS activity.

Treatment with Resveratrol showed a significant decrease in serum NO concentration in rats after 2, 4 and 6 weeks compared with control NAFLD group. these results were nearly similar to Karin, et al., (2012) recorded that a significant decrease in serum NO concentration may be due to stimulation of endolethelial nitric oxide synthase (eNOS) activity; provide in vivo evidence suggesting that resveratrol and red wine improve endothelial function, which may be one of the mechanisms by which this red wine polyphenolexerts its alcohol-independent cardioprotective effect.

On the other hand Randall D. Wight, et al., (2013) stated that a significant decrease in serum NO concentration may be due to the ability of resveratrol to inhibit lipopolysaccharide (LPS)-induced production of inflammatory molecules from primary mouse astrocytes. Resveratrol inhibited LPS-induced production of nitric oxide (NO); suggested that NAD (P) $\mathrm{H}$ oxidase-derived $\mathrm{H} 2 \mathrm{O} 2$ plays a central role in endothelial activation.

These results were in accordance with Bujanda, et al., (2006) observed that a significant decrease in serum NO concentration may be due to the potential mechanisms responsible for its biological activities include down regulation of the inflammatory response through inhibition of the synthesis and release of proinflammatory mediators, modification of eicosanoid synthesis, inhibition of Kupffer cells and adhesion molecules, inhibition of inducible nitric oxide synthase and cyclooxygenase- 2 (COX-2) via its inhibitory effects on nuclear factor (kappa)B (NF-kB) or the activator protein1 (AP-1).

Data presented in table (1,2 and 3) showed that a significant increase in Serum L-MDA after 2, 4 and 6 weeks compared with the normal control group. These results were nearly similar to Feng (2002) revealed that a significant increase in Serum L-MDA may be due to the Assessing peroxidation of lipids entails analyzing lipid peroxides, diene conjugates, isoprostanes, and breakdown products of lipids such as, 
pentane, MDA, and 4-hydroxynonenal of these, malondialdehyde is used most and is believed to be a true index of peroxidation of lipids. In the case of protein oxidation, the majority of researchers have made assessments based on "protein carbonyls", "nitration of protein-bound tyrosine residues", and the "loss of free thiol groups in proteins. They have extensively used protein nitro tyrosine for measuring the production of reactive oxidants with nitrogen such as nitric oxide. Certain DNA base oxidation compounds like 5-OH cytosine, $8-\mathrm{OH}$ adenine, $8-\mathrm{OH}$ guanine and 8 -hydroxydeoxyguanosine, have frequently been used as an indicator in order to evaluate oxidation of DNA.

More ever Catala, (2006) found that Lipid peroxidation - One case of oxidative stress The formation of lipid peroxidation products causes spread of free radical reactions Lipid peroxidation begins with hydrogen atom abstraction. Hydroxyl radical, in its first reaction with PUFA produces a lipid radical (L). This in turn reacts with molecular oxygen to produce a lipid peroxyl radical (LOO) and create a second lipid radical; a lipid hydroperoxide (LOOH). Lipid peroxidation can cause changes in permeability of the membrane transportation of different ions, and also may interrupt its metabolic process. This process of peroxydation produces a whole range of compounds. This process is one of the main results of the damage done to tissues through free radicals.

Treatment with Resveratrol exhibited a significant decrease in serum L- MDA concentration in rats after 2, 4 and 6 weeks compared with control NAFLD group. these results were in agree with Kirimlioglu, et al., (2008); Sehirli et al., (2008) stated that a significant decrease serum L- MDA may be due to Resveratrol treatment to partial hepatectomy rats revealed a significant reduction in MDA levels than those of untreated rats and treatment of naphthalene treated rats with
Resveratrol caused a significant reduction in MDA level toward the control levels.

However Fan, et al., (2009);Farghali, et al., (2009) revealed that may be due to Resveratrol treatment significantly inhibited the LPO $(\mathrm{P} \leq 0.05)$ and reduced peroxidative stress up to $60 \%$, which is an indication of its anti oxidative effect. These results were nearly similar to Palsamy et al., (2010) found that a significant decrease in serum L- MDA concentration in rats after 2, 4 and 6 weeks compared with control NAFLD group may be due to the effect of Resveratrol on the levels of lipid peroxides in control and experimental diabetic groups of rats. And revealed MDA level declined $(p<0.05)$ significantly to near normalcy by the treatment of RSV to diabetic groups of rats.

The obtained results in tables $(1,2$ and 3 ) stated that a significant increase in serum Ig A, IgG concentration was observed in rats after 2, 4 and 6 weeks compared with the normal control group. these results were nearly similar to LiZ et al., (2005); Korn, T., et al., (2009) revealed that A significant increase in serum $\operatorname{IgA}, \operatorname{IgG}$ may be due to the immune cell population, natural killer $\mathrm{T}$ (NKT) cells, which express NK cell markers and $\alpha / \beta \mathrm{T}$ cell receptors, are reduced in steatotic obese mice and the Kupffer cells (KC) are liver macrophages involved in the response to such stressors as infections, ischemia and toxins.

Furthermore Tarantino et al., (2010); Kerkhoffs et al., (2012) found that a significant increase in serum $\operatorname{IgA}, \operatorname{IgG}$ revealed that may be due to $\mathrm{A}$ low-grade chronic inflammation underlies all NAFL Dentities/stages and can develop and promote the liver damage Innate and adaptive immune pathways are activated in obesity and many findings show that adipose tissue inflammation exacerbates hepatic steatosis and promotes nonalcoholic steato-hepatitis (NASH) and The adipose tissue has an important role in regulating energy utilization, vascular functions and immune system homeostasis. 
C-reactive protein (CRP), interleukin(IL)-6, fibrinogen and plasminogen activator inhibitor-1 levels are higher in obese patients compared to healthy subjects have recently found that obese mice, after high fat and high cholesterol diets, express abnormal levels of macrophages and inflammation associated genes in adipose tissue and in liver.

Treatment with Resveratrol exhibited a significant decrease in serum $\operatorname{IgA}, \operatorname{IgG}$ concentration in rats after 2, 4 and 6 weeks compared with control NAFLD group. These results were in accordance with Zou Jian-Ping (2002) who revealed that a significant decrease in serum IgA, IgG may be due to the low dose resveratrol enhanced cell-mediate immune response. Promoting Th1 cytokine production and influencing on macrophage function might be its mechanisms and suppressive effect of ethanol both on macrophage percentage and on macrophage MHC-II molecule expression.

Data presented in Table (1, 2 and 3) showed that a significant increase in Serum AST ,Serum ALT , Serum GGT concentration in rats after 2, 4 and 6 weeks compared with the normal control group. These results were nearly similar to Adams, et al., (2005); Bayard et al., (2006) stated that a significant increase in Serum AST, ALT may be due to fatty infiltrate.

On the other hand Chavez-Tapia, et al., (2012) revealed that the elevation liver enzymes may be due to the NASH animal model there was an increase in serum alanine aminotransferase levels and TNF- $\alpha$, IFN $\gamma$ and TLR4. Higher TNF- $\alpha$ level were detected in $\mathrm{KCs}$ and, most importantly, increased TNF- $\alpha$, TLR4 expression, and macrophage/dendritic cell populations, demonstrating also the involvement of the gut in steatotic liver damage.

However Jain and Singhai, (2011) showed that a significant increase in Serum AST, ALT and GGT Interpreted the elevated levels of AST , ALT and GGT as a result of the hepatocytes damage or alterations in the membrane permeability indicating the severity of hepatocellular damage induced.

Furthermore Sehrawat, et al., (2006) ;Mahmoud, (2011) stated that a significant increase in Serum AST, ALT and GGT may be due to Liver cell destruction results in the leaking out of tissue contents into the blood stream. Serum AST, ALT, and $\gamma$-GT are the most sensitive markers employed in the diagnosis of liver diseases, also due to the liver cell plasma membrane is damaged, numerous enzymes normally located in the cytosol are released into the blood.

Treatment with Resveratrol exhibited a significant decrease in serum AST, serum ALT, serum GGT concentration in rats after 2, 4 and 6 weeks compared with control NAFLD group. these results were nearly similar to de la Lastra et al.,( 2005); Sehirli et al., (2008) found that a significant decrease in serum AST, serum ALT, serum GGT concentration in rats after 2,4and6 weeks compared with control NAFLD group may be due to the resveratrol decrease the liver lesions and transaminase elevations caused by alcohol in mice and decreased hepatic steatosis in an animal model of steatosis and second whether this therapeutic approach resulted in a decrease in tumor necrosis factor $\alpha \mathrm{TNF}-\alpha$ production and oxidative stress.

More ever Fan, et al., (2009); Černý et al., (2009) stated that ALT, AST, and GGT activities significantly decreased towards normal values after RSV treatment $(\mathrm{P} \leq 0.05)$ when compared with $\mathrm{CCl} 4$ treated group.

However Farghali et al., (2009); HassanKhabbar, et al., (2010) revealed that Resveratrol treatment for LPS/D-GalN treated ratssignificantly reduced serum ALT, AST, and GGT activities than LPS/DGalN non treated group. Therefore the Postischemic treatment of rats with low doses of Resveratrol $(0.2 \quad \mathrm{mg} / \mathrm{kg})$ significantly decreased ALT activity by about $40 \%$ compared to the vehicle I/R group, and AST activity was decreased by $45 \%$ compared with the vehicle I/R group. 
On the other hand Schmatz et al., (2012); Lee et al., (2004) determined that treatment with Resveratrol prevented significantly the rise of AST, ALT and $\gamma$-GT activities in the diabetic/RV10 and diabetic/RV20 groups $(\mathrm{P}<0.05)$. Serum GGT might be one of the enzymes related to oxidative stress.

The obtained results demonstrated in tables (1, 2 and 3) showed that a significant decrease in liver CAT, liver SOD and liver GSH concentration compared with the normal control group in rats after 2, 4 and 6 weeks . these results were nearly similar to Valko, et al., (2007) ;Muller, (2009)stated that A significant decrease in liver CAT, liver SOD and liver GSH concentration in rats after 2, 4 and 6weeks compared with the normal control group may be due to Antioxidants Formation of free radicals is naturally checked by a variety of useful compounds called antioxidants. Antioxidants in our body are the first to fight free radicals .The initial encounter leads to neutralization of free radical. This begins a chain reaction. Free radicals are neutralized; thousands of reactions take place instantly.

The antioxidant enzymes such as catalase, glutathione peroxidase, and superoxide dismutase are involved in metabolizing oxidative toxic intermediates. In order to utilize their maximum catalytic potential, they need cofactors like zinc, iron,copper, selenium, and manganese.

On the other hand Min, et al., (2012) showed that the increased mitochondrial ROS can increase hepatocytes Fas-ligand expression with a consequent activation of apoptotic mechanism of hepatocyte death. Lower levels of serum antioxidants are present in patients with NASH. Depletion of antioxidants via lipid peroxidation and free oxygen radical species renders the liver more susceptible to oxidative damage. In fact, treatment with various antioxidants, i.e., glutathione prodrugs (Sadenosylmethionine, betaine, choline), vitamin E, Also alpha lipoic acid, a naturally occurring thiol antioxidant, a hepatoprotective effect, associated with reduced expression of cytochrome P2E1, endoplasmic reticulum stress, and reduction of mitogen-activated protein kinases and $N F-\kappa B$ activity in mice on choline- and methionine-deficient diet.

Treatment with Resveratrol exhibited a significant decrease after 2, 4 weeks, a significant increase after 6 weeks in liver CAT, a significant decrease after 2 , 4and 6 weeks in liver SOD and exhibited a significant increase in liver GSH concentration in rats after 2, 4 and 6 weeks compared with control NAFLD group these results were nearly similar to Valko et al., (2006) stated that these results may be due to cellular metabolic reactions generate small amounts of ROS, including hydroxyl radicals $(\mathrm{OH})$, superoxide anions $(\mathrm{O} 2)$ and hydrogen peroxide (H2O2). Under normal physiological conditions, ROS production is balanced by several cellular antioxidant mechanisms in order to avoid the harmful effects of these species.

In addition to Dickinson, et al., (2002) showed that Cellular metabolic reactions generate small amounts of ROS, including hydroxyl radicals $(\bullet \mathrm{OH})$, superoxide anions $(\mathrm{O} 2 \cdot-)$ and hydrogen peroxide (H2O2). Under normal physiological conditions, ROS production is balanced by several cellular antioxidant mechanisms in order to avoid the harmful effects of these species.

Also Araujo et al., (2008) found that a significant increase may be due to Antioxidant systems are crucial in providing defenses against oxidative cell damage. Glutathione (GSH) is one of the most abundant non-enzymatic antioxidants in all tissues. GSH can scavenge free radicals, reduce peroxides, and be conjugated with electrophilic compounds through enzymatic or non-enzymatic reactions. The oxidation of GSH leads to the production of glutathione disulfide (GSSG). Since GSSG/GSH pair forms the major redox couple in cells.

More ever Jones (2002); Obrosova et al., (2007) showed that this ratio can be used to 
establish the oxidative status of the tissue due to the cell protective actions of the GSH occur through different pathways and ROS, such as superoxide and hydrogen peroxide, are produced under normal conditions through the Mt electron transport chain and are normally removed by cellular detoxification agents such as superoxide dismutase, catalase, and glutathione.

Furthermore Leinninger, et al., (2006); Cheng and Zochodne, (2003) revealed that a significant decrease after 2,4 weeks, a significant increase after 6 weeks in liver CAT may be due to Hyperglycemia leads to increased $\mathrm{Mt}$ activity, raising ROS production in the Mt Peroxynitrite, the primary RNS, is formed by the 'reaction of superoxide and nitric oxide (NO). RNS induces a number of cytotoxic effects including protein nitrosylation and activation of PARP.

These results were in accordance with Obrosova, et al, (2005a) found that a significant decrease after 6 weeks in liver SOD may be due to Peroxynitrite is a product of superoxide anion radical reaction with nitric oxide and that aldose reductase inhibition decreases superoxide abundance and Growing evidence indicates that increased aldose reductase activity leads to diabetes-associated oxidative-nitrosative Stress via several mechanisms. First, aldose reductase is responsible for down regulation of antioxidative defense provided by both non enzymatic antioxidants, i.e., GSH, ascorbate.

On the other hand Obrosova and Fathallah, (2000) exhibited a significant increase in liver GSH concentration in rats after 2,4 and 6 weeks compared with control NAFLD group may be due to antioxidative defense enzymes, i.e., superoxide dismutase, catalase, glutathione peroxidase, glutathione reductase, and glutathione transferase. The present study demonstrated that resveratrol treatment provided an effective treatment against NAFLD in rats, since these compounds were able to ameliorate serum biochemical parameters, antioxidants , immuneglobulins and prevent the lipid peroxidation in the serum and regulate liver function tests.

Conclusion: we recommended that, Administration of diet rich in the natural polyphenols as (resveratrol) is very important for treatment of different body organs, especially liver against oxidative stress or even innate immunity.

\section{Acknowledgment:}

Special thanks for center excellence in scientific research (CESR), faculty of veterinary medicine that funded by management supporting excellence (MSE) and Benha University

\section{REFERENCES}

Adams, L.A., Angulo, P., Lindor, K.D. 2005. Nonalcoholic fatty liver disease. CMAJ, 172 (7): 899-905.

Araujo, A.S., Singal, P. , Bellø-Klein, K.A. 2008. The role of redox signaling in cardiac hypertrophy induced by experimental hyperthyroidism. J. Mol. Endocrinol. 41: 423 - 430.

Bancroft, J.D., Stevens, S.A. 1996. Theory and Practice of Histological Techniques. Churchill-Livingstone, New York. 435470.

Bass, T.M., Weinkove, D., Houthoofd, K., Gems, D., Partridge, L. 2007. "Effects of resveratrol on lifespan in Drosophila melanogaster, Caenorhabditis elegans". Mech. Ageing Dev. 128 (10): 546-52.

Bayard, M., Holt, J., Boroughs, E. 2006. Nonalcoholic fatty liver disease. American Family Physician, 73 (11): 1961-8.

Bleta, G. 1990. Report on the symposium "drug effect in clinical chemistry methods. Eur J. Clin. Chem. Clin. Biochem. 34: 385386.

Bujanda, L., Garca-Barcina, M., Gutiérrez-de Juan, V., Bidaurrazaga, J., FernndezdeLuco, M., Gutiérrez-Stampa, M.A., Larzabal, M., Hijona, E., Sarasqueta, C., Echenique-Elizondo, M., Arenas, J.I. 2006. Effect of Resveratrol on non alcohol-induced mortality and liver lesions in mice. BMC Gastroenterol. 6:35. 
Catala, A. 2006. An overview of lipid peroxidation with emphasisin outer segments of photoreceptors, the chemiluminescence assay. Int. J. Biochem. Cell Biol. 8:1482-95. MacMillan Publishing Company, New York, USA.

Černý, D., Canová, N.K., Martínek, J., Hořinek, A., Kmonickova, E., Zidek, Z., Farghali, H. 2009. Effects of resveratrol pretreatment on tert-butylhydroperoxide induced hepat-ocytetoxicity in immobilized perifused hepatocytes involvement of inducible nitric oxide synthase, hemoxygenase-1. Nitric Oxide, 20:1-8.

Chavez-Tapia, N.C., Rosso, N., Tiribelli, C. 2012. Effect of intracellular lipid accumulation in a new model of nonalcoholic fatty liver disease. BMC Gastroenterol. 12: 20.

Cheng,C., Zochodne, D.W. 2003. Sensory neurons with activated caspase-3 survive long-term experimental diabetes. Diabetes, 52: 2363-2371.

de la Lastra, C.A., Villegas. 2006. Resveratrol as an anti-inflammatory, anti-aging agent mechanisms a clinical implications dependent hepatocyte apoptosis. J. Biol. Chem .281: 12093-191.

Dickinson, P.J., Frost, G. S., Boulton, A. J. 2002. Neurovascular disease, antioxidants, glycation in diabetes. World J. Gastroenterol.13:4539-50.

Emanuela, E.A., Iacono, G.B., Giuseppina, A., Salvatore C. 2013. Oxidative inflammatory liver damage in patients with NAFLD. The Journal of Nutrition, 139: 905-911.

Fan, G., Jiang Jiang Tang, Monika Bhadauri, Satendr Kumar Niral, Fang Dai, Bo Zhou, Yang Li , Zhong Li Liu. 2009. Resveratrol ameliorates carbontetrachloride-induced acute liver injury in mice Environmental Toxicology, Pharmacology. 28: 350-356.

Fang, J.G., Lu, M., Chen, Z.H., Zhu, H.H., Li, Y., Yang, L. 2002. Antioxidant effects of resveratrol, its analogues against the free radical induced peroxidation of linoleic acid in micelles. Chemistry European Journal, 8(18): 4191-4198.

Farghali, H., Cerny, D., Kamenıkova, L., Martinek, J., Horinek, A., Kmonickova, E., Zidek, Z. 2009. Resveratrol attenuates lipo-polysaccharide - induced hepatitis in D- galactosamine sensitizedrats: role of nitric oxide synthase 2 , heme oxygenase1. Nitric Oxide, 21:216-225.

Hassan-Khabbar, S., Vamy, M., Cottart, C.H. 2010. Protective effect of post-ischemic treatment with trans-resveratrol on cytokine production and neutrophil recruitment by rat liver. Biochimie, 92: 405-410.

Jain, N.K., Singhoi, A.K. 2011. Protective effects of phullanthus acidus (1) skeels leaf extracts on acetaminophen and thoioacetamide induced hepatic injuries in Wister rats. Asian pacific Journal of Tropical Medicine. 4: 470-474.

Jeanne, M., Clark, M.D., M.P.H., Anna Mae Diehl, M.D. 2003. Nonalcoholic fatty liver Disease an under recognized Cause of Cryptogenic Cirrhosis. JAMA $.289(22): 3000-3004$

Jiang-Gangzou, Zhi-Rong Wang, Yuan-Zhu Huang, Ke-Jlang Cao, Joseph, M. W.u. 2003. Effect of red wine and wine polyphenol resveratrol on endothelial function in Hyper-cholesterolemic rabbits (3 $\mathrm{mg} / \mathrm{kg} /$ day) (RES group). International Journal of Molecular Medicine .11:317-320.

Jones, P.J. 2002. Clinical Nutrition: Functional Foods - More Than Just Nutrition. CMAJ, 166: 1555-1563.

Karine Clement, Nathalie Viguerie, ChristinePoitou, Claire Carette, Veronique Pelloux,CyrileaCurat, Audrey Sicard, Sophie Rome, Arriel Benis, JeandanielZucker, Hubertvidal, Amartine Laville, Gregory S. Barsh, Arnaud Basdevant, Vladimir Stichraffaella Cancello, Dominique Langin. 2012. Weight loss regulates inflammationrelated genes in white adipose tissue of obese subjects. The FASEB. JRCD of Pediatrics, Genetics, Howard, D.L., UPS U586, Institut.

Kerkhoffs, G.M., Servien, E., Dunn, W., Dahm, D., Bramer, J.A., Haverkamp, D. 2012. The influence of obesity on the complication rate and outcome of total knee Arthroplasty a meta-analysis and systematic literature review. J. Bone Joint Surg. Am 20.

Kirimlioglu, H., Ecevit, A., Yilmaz, S., Kirimlioglu, V., Bay Karabulut, A. 2008. Effect of Resveratrol, Melatonin on 
Oxidative Stress Enzymes, Regeneration, Hepatocyte Ultrastructure in Rats Subjected to $70 \%$ Partial Hepatectomy. Transplantation Proceedings, 40: 285289.

Korn, T., Bettelli, E., Oukka, M., Kuchroo, V.K. 2009. IL-17, Th17 Cells. Annu. Rev Immunol. 27: 485-517.

Lee, D.H., Steffen, L.M., Jacobs, D.R. 2004. Association between serum gammaglutamyltransferase and dietary factors. Am. J. Clin. Nutr.79:600-605.

Leinninger, G.M., Lipshaw, M.J., Feldman, E.L. 2006. Mechanisms of disease: mitochondria as new therapeutic targets in diabetic neuropathy. Nat. Clin. Pract. 2 (11); 620-628.

Li Z, Soloski, M.J., Diehl, A.M. 2005. Dietary factors alter hepatic innate immune system in mice with nonalcoholic fatty liver disease. Hepatology, 42: 880-885.

Luck, H. 1974. Estimation of catalase. In methods in enzymatic analysis $2^{\text {nd }}$ edition, Bergmeyer, Academic Press, New York. 885- 890.

Mahmoud, A.M. 2011. Influence of rutin on biochemical alterations in hyperammonemia in rats. Experimental Toxicologic Pathology, 582:139-146

Mesbah, L., Soraya, B., Narimane, S., Jean, P.F. 2004. Protective effect of flavonides against the toxicity of vinblastine cyclophosphamide and paracetamol by inhibition of lipid - peroxydation and increase of liver glutathione. Haematol. 7 (1): 59-67.

Min, A.K., Kim, M.K., Kim, H.S., Seo, H.Y., Lee, K.U., Kim, J.G. 2012. Alpha-lipoic acid attenuates methionine choline deficient diet-induced steatohepatitis in C57BL/6 mice. Life Sci. 90:200-510.

Moron, M.S., Depierre, J.W., Mannervik, B. 1979. Levels of glutathione, glutathione reductase, glutathione S-transferase activities in rat lung and liver. Biochimicaet Biophysica, 582: 67-78.

Muller, M. 2009. Cellular senescence molecular mechanisms, in vivo significance, and redox considerations. Antioxid. Redox Signal, 11: 59 - 98.

Murray. 1984. Report on the symposium "drug effect in clinical chemistry methods for Estimation of AST. Eur. J. Clin. Chem. Clin. Biochem. 34:1112-1116.
Nishikim, M., Roa, N.A., Yogi, K. 1972. Colorimetric determination of superoxide dismutase (SOD). Biochem. Bioph. Res. Common. 45: 849-854.

NRC (National Requirments of Laboratory animals) fourth revised edition.1995.subcommittee on laboratory Animal Nutrition, National Research Conuncil, National Academy Press, Washington , D.C.Of the lipid lowering agents clofibrate and BM15.075.

Obrosova, I.G., Drel, V.R., Groves, J.T. 2007. Role of nitrosative stress in early neuropathy, vascular dysfunction in streptozotocin-diabetic rats. Am. J. physiol. 293 (6): E1645-E1655.

Obrosova, I.G., Drel, V.R., Wang, Z.Q., Stevens, M.J. 2005. Oxidativenitrosative stress, poly (ADP-ribose) polymerase (PARP) activation in experimental diabetic neurpathy: the relation is revisited. Diabetes, 54: (12): 3435-3441.

Obrosova, I.G., Fathallah, L., Greene, D.A. 2000. Early changes in lipid peroxidation, antioxidative defense in diabetic rat retina, effect of DL- $\alpha$-lipoic acid. Eur. J. Pharmacol. 398: 139-146.

Oyadomari, S., Gotoh, T., Aoyagi, K., Araki, E., Shichiri, M., Mori, M. 2001. Conduction of endothelial nitric oxide synthase, arginine recycling enzymes in aorta of diabetic rats, pathology management issues for non-alcoholic fatty acid. Nitric Oxide .5: 252-260.

Palsamy, P., Sivakumar, S., Subramanian, S. 2010. Resveratrol attenuates hyperglycemia-mediated oxidative stress, pro-inflammatory cytokines, protects hepatocytes ultra-structure in streptozotocin-nicotinamide-induced experimental diabetic rats. ChemicoBiological Interactions, 186:200-210.

Randall, D., Wight Cameron, A., Tull Matthew, W., Deel, Brooke, L., Stroope, Amy, G., Eubanks, Janet, A., Chavis, Paul, D., Drew, Lori, L., Hensley. 2013. Resveratrol effects on a strocyte function. Relevance to neurodegenerative diseases .Department of Biology, Ouachita Baptist University, Arkadelphia, AR 7United States Received 01-30 Accepted 07-01.

Reuters. 2010. "Pharma seeks genetic clues to healthy aging"6:4. 
Schmatz, R., Perreira, L.B., Stefanello, N., Mazzanti, C., Spanevello, R., Gutierres, J., Bagatini, M., Martins, C.C., Abdalla, F.H. 2012. Effects of resveratrol on biomarkers of oxidative stress, on the activity of delta aminolevulinic acid dehydratase in liver, kidney of streptozotocin-induced diabetic rats Biochimie. 94: 374-383.

Sehirli, O., Tozan, A., Omurtag, G.Z., Cetinel, S., Contuk, G., Gedik, N., Sener, G. 2008. Protective effect of resveratrol against naphthalene-induced oxidative stress in mice. Ecotoxicol. Environ. Saf. 71: 301308.

Sehrawat, A., Khan, T.H., Prasad, L., Sultana, S. 2006. Butea monosperma chemomodulation protective role against thioacetamide mediated hepatic alterations in Wistar rats. Phytomedicine .13: 157-163.

Slatter, D.A., Bolton, C.H., Bailey, A.J. 2000. The importance of lipid-derived malondialdehyde in diabetes mellitus. Diabetologia, 43: 550-557.

Stastical Analysis system (SAS). 2002. Version 9.00 .S.A.S Institute Inc., cary, NC, USA.

Stenvinkel, P. 2001. Endothelial dysfunction, inflammation is there a link? Nephrol. Dial. Transplant.16: 1968-1971.

Steven Reinberg. 2014. Resveratrol in Red Wine Not Such a Health-Booster? Health Day Reporter .5: 12, (Health Day News).

Tarantino, G., Savastano, S., Colao, A. 2010. Hepatic statuses, low gradechronic inflammation, hormone growth factor adipokine imbalance. World J. Gastroenterol., 16:4773-4783.

Valko, M., Cronin, M.T., Mazur, M., Telser, J. 2007. Free radicals, antioxidants in normal physiological functions, human disease. Int. J. Biochem. Cell Biol. 39: 44 -84 .

Valko, M., Rhodes, C.J., Moncol, J., Izakovic, M.M. 2006. Mazur, Free radicals, metals, antioxidants in oxidative stress-induced cancer, Chem. Biol. Interact. 23: 695701.

Vodovotz, Y. 1996. Modified microassay for serum nitrite, nitrate. Biotechniques, 20: 390-394.

Walter Bottje, Boonprom Enkvetchakul, Robert, F., Wideman, J.R. 2006. Antioxidants, Hypoxia, Lipid
Peroxidation Involvement in Pulmonary Hyprtension Syndrome. Ascites, 22: 9.

Whicher, J.T., Warronc, chammber, R.E. 1984. Immunochemical assay for Igs. Ann. Clin. Biochem. 21: 78-91.

Zou Jian-Ping. 2002. Promoting Th1 cytokine production and influencing on Macrophage function might be its mechanisms. The national natural science foundation of China, 2: 6431-1833. 